\author{
Amber Dierking \\ Grand Valley State University, MI, USA
}

Dr. Julia Bullard

University of British Columbia, BC, Canada

\title{
THE LANDSCAPE OF CONTEMPORARY CANADIAN SUBJECT ACCESS (Paper)
}

\begin{abstract}
Résumé:
Subject access in Canada, whether through subject headings, classification, thesauri or other structures, is dominated by systems originally created in the United States. Building on a 2019 literature review that identified current subject access systems and developing projects in the Canadian context, this paper will explore the patterns of divergence and convergence between systems and across borders. As subject access systems from the United States do not meet all the needs of Canadian scholarship, next steps include considering how these gaps and distortions impact Canadian scholarship and what institutions in Canada are doing to create systems consistent with their values.
\end{abstract}

\section{Introduction}

Currently in Canada the primary systems of bibliographic subject access are adaptations or derivatives of systems developed originally in the United States (US). Although the landscape of Canadian subject access is dominated by US institutions and systems, they often do not meet the needs of Canadian context and scholarship. Building on a literature review which identified Canadian-born subject access systems currently in use or being developed, this paper will explore the ways in which Canadian systems have derived, diverged, or converged from and into US precedents and contemporaries. Paying particular attention to Canada's multilingual and multicultural context, this paper will use the literature review as a starting point to identify patterns in the evolution of the landscape of Canadian subject access, considering the impact of these trajectories on Canadian research and scholarship.

\section{Literature Review}

Conducted in the Spring of 2019, this literature review identified 44 projects, 15 of which are adaptations of some kind, and 29 which are standalone projects. The aim for the scope of this review was to be as comprehensive as possible in terms of subject matter. Our broad definition of subject access included multiple forms of knowledge organization, including classification systems, subject heading languages, taxonomies and thesauri, among others. To balance this broad subject, the scope was refined and narrowed in other ways. For example, the timeframe was limited to exclude anything published pre-2000 and the review was geographically limited 
as well to focus on projects that were either created, or actively used, in Canada. However, there were several projects or papers from international contexts that were also valuable to consider. These included multilingual projects in Europe that evolved partially from Canadian systems (Bélair 2005; Landry 2004), as well as several Indigenous knowledge organization projects from the United States (Lincoln 2003; Littletree \& Metoyer 2015; Martens 2006; Powell 2007).

\subsection{Patterns and sites of significant focus}

Of those projects and systems created in Canada, the most well documented pertain to Indigenous knowledge organization (IKO) in some way, these being the Brian Deer Classification System (BDCS), the adaptations of BDCS at Xwi7xwa (Doyle 2006), the Union of British Columbia Indian Chiefs (Cherry \& Mukunda 2015), and at the Aanischaaukamikw Cree Cultural Institute (Swanson 2015). Additional IKO systems include the First Nations House of Learning (FNHL) subject headings (Doyle, Lawson, \& Dupont 2015), Digital Library North (Farnel et. al. 2017; Shiri \& Stobbs 2018), and the Modifications to LCSH for use by Manitoba Archives (MAIN) (Bone 2016; Bone \& Lougheed 2018). These examples represent just a few of the systems of IKO actively in use or being developed in Canada today.

Another area of ongoing research in the realm of Canadian subject access is the bi- or multilingual capabilities of these systems. In some instances, systems are fully bilingual such as the Parks Canada Classification system (Dunn 2015). However, it is also common to use separate but complementary English and French systems. For example, Canadian Subject Headings and Le Répertoire de Vedettes-Matière are regularly used in tandem (Desrochers 2013; Dolbec 2006). Others like the Inuit Language Cataloguing Standards are multilingual (Rigby 2015). One additional project stands out as an active site of research and investigation, this being the Taxonomy for Image Indexing And RetrievAl (TIIARA). Despite this project's Canadian origins, it has moved away from localization in favor of interoperability with international standards and audiences (Ménard \& Dorey 2014). TIIARA is not alone in its international focus, other Canadian-born systems that frame themselves as universal include Basic Concepts Classification (Szostack 2012) and Universal Binary Classification (Fadaie Araghi, 2004).

Many of the systems already named are located or produced within academic libraries, or through Library and Archives Canada. Outside of these primary sites, but still firmly within the realm of subject access, are provenance or function-based systems such as the CODOC, the Cooperative Documents System (Lambert 2011) and Business-based Classification Structure (BCS) in the governmental realm (Park \& Neal 2012). Canadian-born subject access systems for youth materials include sur F, a student interest-based classification system, (Gibson 2011) and Exercise, Symbolique, Assemblage, Règles (ESAR), a system for organizing games (Filiatrault, 2014). Other projects which are also slightly outside the traditional library context include the Hansard Index, the primary method of subject access in parliamentary proceedings and therefore also parliamentary libraries (McClung 2009), as well as Keysigns - the only identified project to address subject access in American Sign Language (ASL) or Langue des Sourds du Québec (LSQ), the two most dominant sign languages in Canada (Goodrum 2008).

\section{Discussion}

Perhaps unsurprisingly, due to the breadth of types of systems and their manifold applications, there is a notable lack of theoretical consistency among these projects. More surprising, however, 
was the lack of theoretical work in general. This may, in part, be due to the fact that much of the documentation of these systems is project-based. For although the theoretical basis for many of these projects often went unmentioned, many more did refer fairly clearly to methodological approaches and workflows. Several exceptions have to be made, certainly there were several projects actively working with and centering Indigenous epistemologies. Within this particular lens, specific approaches emphasized relationally, participatory structures, and iterative processes (Cherry \& Mukunda 2015; Doyle, Lawson, \& Dupont 2015; Farnel et. al. 2018; Laroque 2018; Swanson 2015) Other projects, namely those with universal aims, drew on classic principles of classification and its canonical developments, naming Ranganathan and Coates (Fadaie Araghi 2004; Szostack 2012).

Several gaps in the literature were identified. One of the most striking was a lack of any documentation of subject access in non-official, yet widely-spoken languages in Canada, such as Mandarin, Cantonese, or Punjabi. It should be noted, however, that although bi/multilingualism and multiculturalism were all used as search terms during the literature review, specific languages were not. Furthermore, it is entirely possible that research and discussions of these languages and their intersections with English and/or French in the bibliographic world are happening, just simply outside of an explicitly Canadian context, or outside of the more traditional avenues of academic publishing that this review was limited to. Certainly, there are other countries which, like Canada, have official bi or multilingual status and therefore must also cope with such issues in their own systems.

Ultimately, although many Canadian-born systems of subject access were identified in this literature review, the majority of subject access systems in Canada which receive the highest quantity of use are derivatives or adaptations of those created in the United States. Additionally, much of the current scholarship within the discipline of library and information science which refers to multilingualism or multiculturalism is either very broadly web-based and not specific to Canada, or is focused on immigration, collections, or programming services rather than subject access or knowledge organization. The majority of active, Canadian, projects that combine multilingual subject access with a rigorous theoretical basis are in some way connected to Indigenous communities who are perhaps best suited, and may feel more urgency, to subvert the western paradigms and epistemologies that support dominant systems of subject access and knowledge organization.

\section{Conclusion}

While the literature review focused on the preliminary work of identifying ongoing projects, their characteristics, and knowledge organization specialists' approach to creating subject access for the Canadian context, this presentation has expanded upon that information to reveal patterns in their evolutionary trajectories and the gaps that remain between US subject access and Canadian context, values, and priorities. Future steps of this project will include investigating the extent of these gaps, the distortions they create within the infrastructure of Canadian subject access, and the awareness of such a distortion among the scholars who navigate this infrastructure. 


\section{Reference List:}

Bélair, Jo-Anne, Françoise Bourdon, and Michel Mingam. (2005). "Le répertoire de vedettes-matière et RAMEAU: Deux langages d'indexation en français: Un luxe nécessaire." Paper presented at World Library and Information Congress: 71st IFLA General Conference and Council, Oslow, Norway, August 17. http://archive.ifla.org/IV/ifla71/papers/145f-Belair_Bourdon_Mingam.pdf.

Bone, C. (2016). Modifications to the Library of Congress Subject Headings for use by Manitoba archives (pp. 1-8). Presented at the IFLA World Library and Information Congress, Columbus, Ohio. https://doi.org/10.5203/ss_ama.main_bon.chr.2015.1

Bone, C., \& Lougheed, B. (2018). Library of Congress Subject Headings Related to Indigenous Peoples: Changing LCSH for Use in a Canadian Archival Context. Cataloging \& Classification Quarterly, 56(1), 83-95. https://doi.org/10.1080/01639374.2017.1382641

Cherry, A. \& Mukunda, K. (2015) A Case Study in Indigenous Classification: Revisiting and Reviving the Brian Deer Scheme, Cataloging \& Classification Quarterly, 53:5-6, 548-567, DOI: 10.1080/01639374.2015.1008717

Desrochers, N. (2013). Bilingual conundrums: A study of the use of subject headings pertaining to québec as a distinct Society/Équivalences énigmatiques : Représentation du québec en tant que société distincte dans les systèmes de vedettes-matière. Canadian Journal of Information and Library Science, 37(1), 1-23. doi:10.1353/ils.2013.0005

Dolbec, D. (2006). Le répertoire de vedettes-matière : Outil du XXIe siècle. Documentation Et Bibliothèques, 52(2), 99-108. doi:10.7202/1030013ar

Doyle, A. (2006). Naming and reclaiming Indigenous knowledges in public institutions: Intersections of landscape and experience. In G. Budin, C. Swertz, \& K. Mitgutsch (Eds.), Advances in Knowledge Organization: Vol. 10. Knowledge Organization for a Global Learning Society: Proceedings of the Ninth International ISKO Conference, 4-7 July 2006, Vienna, Austria (pp. 435-442). Würzberg, Germany: Ergon. Retrieved from http://arizona.openrepository.com/arizona/bitstream/10150/105581/1/Naming_and_Reclaiming_ Doyle06.pdf

Doyle, A. M., Lawson, K., \& Dupont, S. (2015). Indigenization of knowledge organization at the Xwi7xwa library. Journal of Library and Information Studies, 13(2), 107-134. doi:10.6182/jlis.2015.13(2).107

Dunn, H. (2015). Adopting a Classification System for Collections of Cultural Objects: A comparison of Nomenclature 4.0 and the Parks Canada Classification System. Retrieved from https://www.canada.ca/en/heritage-information-network/services/collections-documentationstandards/adopting-classification-system-collections.html

Fadaie Araghi, G. (2004) A New Scheme for Library Classification, Cataloging \& Classification Quarterly, 38:2, 75-98, DOI: 10.1300/J104v38n02_07

Farnel, S., Koufogiannakis, D., Laroque, S., Bigelow, I., Carr-Wiggin, A., Feisst, D., \& Lar-Son, K. (2018). Rethinking representation: Indigenous peoples and contexts at the university of alberta libraries. The International Journal of Information, Diversity, \& Inclusion (IJIDI), 2(3) doi:10.33137/ijidi.v2i3.32190

Farnel, S., Shiri, A., Campbell, S., Cockney, C., Rathi, D., \& Stobbs, R. (2017). A community-driven metadata framework for describing cultural resources: The digital library north project. Cataloging \& Classification Quarterly, 55(5), 289-306. doi:10.1080/01639374.2017.1312723

Filiatrault, M. \& Hudon, M. (2014). De la classification et des jeux : l'expérience de l'UQO au campus de Saint-Jérôme. Documentation et bibliothèques, 60, (4), 174-188. https://doi.org/10.7202/1026486ar

Gibson, M. (2011). Innovative 21st century classification schemes for elementary school libraries. Feliciter, 57(2), 48. 
Goodrum, A., Hibbard, E., Fels, D., \& Woodcock, K. (2008). The Creation of Keysigns: American Sign Language Metadata. Culture and Identity in Knowledge Organization: Proceedings of the tenth international ISKO conference, 5-8 august 2008, Montréal, Canada.

Holley, R. P. (2008). Subject access tools in english for canadian topics. Library Resources \& Technical Services, 52(2), 29-43. doi:10.5860//rts.52n2.29

Lambert, F. (2011) Do Provenance-Based Classification Schemes Have a Role in Libraries and Information Centres? The Case of Classifying Government Publications, Cataloging \& Classification Quarterly, 49:3, 208-222, DOI: 10.1080/01639374.2011.548053

Landry, P. (2004) Multilingual Subject Access: The Linking Approach of MACS, Cataloging \& Classification Quarterly, 37:3-4, 177-191, DOI: 10.1300/J104v37n03_11

Laroque, S. (2018). Making meaningful connections and relationships in cataloguing practices: The decolonizing description project at university of alberta libraries. Evidence Based Library and Information Practice, 13(4), 2-6. doi:10.18438/eblip29440

Lincoln, T. (2003). Cultural reassertion of Alaska native languages and cultures: Libraries' responses. Cataloging \& Classification Quarterly, 35(3/4), 265-290. doi:10.1300/J104v35n03_01

Littletree, S. \& Metoyer, C. A. (2015) Knowledge Organization from an Indigenous Perspective: The Mashantucket Pequot Thesaurus of American Indian Terminology Project, Cataloging \& Classification Quarterly, 53:5-6, 640-657, DOI:10.1080/01639374.2015.1010113

Martens, M. (2006). Creating a supplemental thesaurus to LCSH for a specialized collection: The experience of the National Indian Law Library. Law Library Journal, 98(2), 287-297. Retrieved from http://www.aallnet.org/main-menu/Publications/llj/LLJ-Archives/Vol98/pub_llj_v98n02/2006-16.pdf

McClung, J. (2009). Herding cats: Indexing british columbia's political debates using controlled vocabulary. The Indexer, 27(2), 66-69.

Ménard, E., \& Dorey, J. (2014). TIIARA: A new bilingual taxonomy for image indexing. Knowledge Organization, 41(2), 113-122. doi:10.5771/0943-7444-2014-2-113

Park, S., \& Neal, D. R. (2012). A new wave of government information management: The development of a function-based classification structure in a canadian government organization. Journal of Library Metadata, 12(1), 23-38. doi:10.1080/19386389.2012.652569

Powell, T. B. (2007). A drum speaks: A partnership to create a digital archive based on traditional ojibwe systems of knowledge. RBM: A Journal of Rare Book, Manuscripts, and Cultural History, 8(2), 167-180. doi:10.5860/rbm.8.2.290

Rigby, C. (2015) Nunavut Libraries Online Establish Inuit Language Bibliographic Cataloging Standards: Promoting Indigenous Language Using a Commercial ILS, Cataloging \& Classification Quarterly, 53:5-6, 615-639, DOI: 10.1080/01639374.2015.1008165

Shiri, A., \& Stobbs, R. (2018). Community-driven user evaluation of the inuvialuit cultural heritage digital library. Proceedings of the Association for Information Science and Technology, 55(1), 440-449. doi:10.1002/pra2.2018.14505501048

Swanson, R. (2015). Adapting the Brian Deer Classification System for Aanischaaukamikw Cree Cultural Institute. Cataloging \& Classification Quarterly, 53(5-6), 568-579. https://doi.org/10.1080/01639374.2015.1009669

Szostak, R. (2012). Classifying relationships. Knowledge Organization, 39(3), 165-178. doi:10.5771/0943-7444-2012-3-165 